\title{
The role of regulatory capital in international bank mergers and acquisitions
}

Citation for published version (APA):

Valkanov, E., \& Kleimeier, S. (2005). The role of regulatory capital in international bank mergers and acquisitions. METEOR, Maastricht University School of Business and Economics. METEOR Research Memorandum No. 018 https://doi.org/10.26481/umamet.2005018

Document status and date:

Published: 01/01/2005

DOI:

10.26481/umamet.2005018

Document Version:

Publisher's PDF, also known as Version of record

\section{Please check the document version of this publication:}

- A submitted manuscript is the version of the article upon submission and before peer-review. There can be important differences between the submitted version and the official published version of record.

People interested in the research are advised to contact the author for the final version of the publication, or visit the DOI to the publisher's website.

- The final author version and the galley proof are versions of the publication after peer review.

- The final published version features the final layout of the paper including the volume, issue and page numbers.

Link to publication

\footnotetext{
General rights rights.

- You may freely distribute the URL identifying the publication in the public portal. please follow below link for the End User Agreement:

www.umlib.nl/taverne-license

Take down policy

If you believe that this document breaches copyright please contact us at:

repository@maastrichtuniversity.nl

providing details and we will investigate your claim.
}

Copyright and moral rights for the publications made accessible in the public portal are retained by the authors and/or other copyright owners and it is a condition of accessing publications that users recognise and abide by the legal requirements associated with these

- Users may download and print one copy of any publication from the public portal for the purpose of private study or research.

- You may not further distribute the material or use it for any profit-making activity or commercial gain

If the publication is distributed under the terms of Article $25 \mathrm{fa}$ of the Dutch Copyright Act, indicated by the "Taverne" license above, 


\title{
The Role of Regulatory Capital in International Bank Mergers and Acquisitions
}

\author{
by \\ Emil Valkanov \\ ProCredit Bank, Bulgaria \\ $\&$ \\ Stefanie Kleimeier* \\ Maastricht University
}

\begin{abstract}
$\underline{\text { Abstract }}$
When investigating the role of regulatory capital in bank mergers and acquisitions (M\&As) we finds that i.e. US targets are better capitalized than their acquirers and non-acquired peers and that US banks maintain higher capital than European banks. Thus, US banks strategically raise their capital levels to avoid regulatory scrutiny. Furthermore, more value is created for targets with higher excess capital and in M\&As involving targets with considerably higher excess capital ratios than their acquirers. Thus, the excess regulatory capital hypothesis is supported. The market prices the influence that capital has on the probability of the merger's regulatory approval.
\end{abstract}

Keywords: Bank mergers and acquisitions, Basle Accord, risk-based capital requirements, excess regulatory capital, shareholder value.

JEL codes: G21, G28, G34.

* Corresponding author: Maastricht University, Faculty of Economics and Business Administration, Limburg Institute of Financial Economics, P.O. Box 616, 6200 MD Maastricht, The Netherlands; email: s.kleimeier@berfin.unimaas.nl, phone: +31-43-3883733, fax: +31-43-3884875. 


\section{INTRODUCTION}

The financial services industry around the globe is consolidating. Starting in the United States (US) in the 1980s, a wave of bank merger reached Europe in the 1990s. From 1997 to 1999 merger activity in the financial sector reached unprecedented heights with approximately 900 transactions per year in total worth 1.2 trillion US dollar (\$) in the Group of Ten countries alone. ${ }^{1}$ This represents a threefold increase in the number and a tenfold increase in the value of deals compared to 1990. In the US, the number of commercial banks has consequently fallen from more than 15000 banks in 1984 to just around 8500 in 1999. Although some banks failed and some new banks were formed during this period, bank M\&As accounted for the elimination of around 7000 banks. Similarly, around 2500 M\&As involving credit institutions took place in the European Union only in the period from 1995 to the first half of $2000 .^{2}$ Since 2000 there is no indication that the merger wave is slowing down.

A few regulatory developments have largely facilitated this process. In the United States, restrictions on banks' ability to expand geographically were relaxed in the 1980s and 1990s and ultimately removed in 1994 with the passage of the Riegle-Neal Interstate Banking and Branching Efficiency Act. ${ }^{3}$ The act overturned the McFadden Act of 1927, which had prohibited banks from branching across states, and, in practice, established the basis for a true nationwide banking system. More recently, the Gramm-Leach-Bliley Financial Services Modernization Act of 1999 overturned the Glass-Steagall Act of 1933, which had separated commercial from investment banking activities. This paved the way for the creation of a universal banking system, with commercial banks providing a full range of banking, securities, and insurance services, all

\footnotetext{
${ }^{1}$ See Group of Ten (2001).

${ }^{2}$ See Wheelock and Wilson (2004) and European Central Bank (2000) for US and European data, respectively.

${ }^{3}$ Berger, Kashyap and Scalise (1995) provide a comprehensive (year-by-year) account of the changes in US laws.
} 
within the authority of a single legal entity, and stimulated consolidation across financial service activities. In the European Union (EU), the ongoing integration of national economies has had a similar effect on the banking industry. More specifically, the Second Banking Directive of 1989 introduced the idea of a single banking license valid throughout the EU and established the universal banking structure for all member states. The creation of the European Monetary Union has put all banks under the supervision of the European Central Bank. More recently, the introduction of the single currency has targeted financial and banking market integration. Banks have responded by seeking to consolidate their positions via M\&As to achieve competitive viability in the single European market.

The effects of consolidation on banks and the banking market as a whole have been extensively researched. It is generally accepted that mergers can result in overall benefits due to increased efficiency from economies of scale and scope, cost reductions through elimination of redundancies, reduced earnings volatility through diversification, and revenue enhancement through increased market power. In this paper we propose and investigate another possible factor that could play a role in the consolidation of the banking industry: Regulatory bank capital. Somewhat surprisingly, the role of capital in bank M\&As seems to have been neglected by researchers. Only a few studies touch on the issue, and only one of them does so with regulatory capital in mind. This lack of research may well reflect a belief among practitioners and academics that bank capital is not a major consideration in the decision to merge. However, a self-contained investigation of the role of regulatory capital in bank M\&As is warranted for at least two reasons. First, whatever the results of such a study, it will contribute to a fuller picture and a better understanding of the causes and consequences of bank consolidation. Second, and more importantly, there seems to be a valid reason why capital should play a role in bank consolidation: Under the current Basle I Accord capital adequacy standards, a bank is required to 
maintain $4 \%$ of Tier 1 capital and $8 \%$ of Total capital relative to its risk-weighted assets. However, many banks maintain capital levels in excess of these regulatory minima. There could be a number of reasons for that, the most important of which being risk-averse managers, who want to maintain a cushion for protection against poor performance or unexpected losses. However, low-capital banks have a higher equity multiplier than their high-capital counterparts and are, therefore, able to provide higher returns on equity (ROE). Consequently, the former have a competitive advantage over the latter, because they can reduce return on assets (ROA) by cutting prices or expanding their asset base, while still providing competitive returns to shareholders. However, if relatively high-capital banks provide lower returns to shareholders and are less competitive, they may be especially attractive as merger or acquisition targets because of the post-acquisition possibility for the acquiring bank to reduce the capital holdings of the acquired institution and increase returns to shareholders. Therefore, the question of whether banks with high levels of regulatory capital are more attractive as targets is of particular interest.

Based on a sample of 105 US and European bank mergers from 1997 to 2003 our analysis and results can be summarized as follows: Mean difference tests reveal that i.e. US target banks are better capitalized than their acquirers and non-acquired peers. Event study analysis show that in US M\&As value is created for target banks' shareholders but destroyed for acquiring banks' shareholders. In contrast, European M\&As create shareholder wealth for both groups. Here targets and - at least in the short-run - acquirers display positive abnormal returns. Bank capital levels play a double role as is revealed by quartile comparisons and regression analysis: First, high-capital targets compared to low-capital targets create more value. Second, mergers involving target banks with considerably higher capital ratios than their acquirers create more value than mergers where the target has the same or lower capital ratios than the acquirer. 
We thus conclude that an acquisition premium exists for the target bank and the market prices the positive influence that regulatory capital has on the probability of the merger being approved by regulators. Finally there is also some marginal evidence that the potential of the acquiring bank to reduce the excess capital holdings of the target institution is valued by the market and this upside potential accrues to the acquiring banks' shareholders.

\section{THE BASLE ACCORD RISK-BASED CAPITAL REQUIREMENTS ${ }^{4}$}

The 1988 Basle Accord is a landmark regulatory agreement as for the first time laws and regulations affecting banks in many different countries were jointly established. By setting uniform capital requirements, the Basle Accord aimed at reducing the risk of the international banking system and at reducing the competitive inequality that arose from differences among national bank-capital regulations. ${ }^{5}$ Before the Accord, cross-country comparisons of the capital levels of international banks were difficult since national definitions of bank capital differed substantially. Thus, before establishing international regulatory standards for capital adequacy, a common definition of capital was needed. The Accord provides such a common international definition of bank capital that divides capital into two tiers as shown in Table 1. Tier 1 capital is common to all of the member countries, thus making it useful for cross-country comparisons. It

\footnotetext{
${ }^{4}$ Most information in this chapter is based on Bank for International Settlements (1989).

${ }^{5}$ Regulators and bankers argued that different capital rules gave banks with low capital requirements an advantage over banks subject to higher capital requirements. By increasing their asset base or reducing prices, low-capital banks could accept lower returns on assets to achieve a given return on equity and thereby increase their market share. This had allowed Japanese banks to capture more than one-third of international lending during the 1980s. Thus, the ultimate goal of the Accord was to eliminate the pricing advantage of Japanese banks and create a more level playing field across countries.
} 
consists of the most permanent forms of capital, such as ordinary shares or common stock (including retained earnings) and disclosed reserves, less goodwill. Some forms of preferred stock (non-cumulative perpetual preferred stock) are also considered part of Tier 1 capital by US bank holding companies. The second type of capital, Tier 2 capital consists of elements that at least one member country considers bank capital. Thus, it can include any combination of the eligible capital elements permitted by the national regulator. Generally, Tier 2 capital represents less permanent forms of capital, or capital that carries a fixed or cumulative cost, such as general provisions, redeemable preference shares, cumulative preferred stock, hybrid instruments or subordinated debt.

[Insert Table 1 about here]

In addition to providing a common definition of bank capital, the Accord requires international banks to hold Total capital (Tier 1 plus Tier 2 capital) equal to at least $8 \%$ of a basket of assets measured in different ways according to their riskiness. The Accord assigns various weights to broad categories of credit risk in a bank's asset portfolio $(0,10,20,50$, and $100 \%$ ). Low credit risk assets, such as cash or Treasury securities issued by an OECD country, have a $0 \%$ risk-based capital requirement. In contrast, claims on commercial companies and real estate investments have a 100\% risk weight. Off-balance sheet exposures (bank guarantees, letters of credit, etc.) are included with their appropriate conversion factors. The sum of weighted assets constitutes adjusted total assets (or risk-weighted assets) of which $8 \%$ (4\% in Tier 1 elements and 4\% in Tier 2 elements) is the minimum capital base. Tier 2 capital is only eligible up to $100 \%$ of Tier 1 capital. A 1996 amendment to the 1988 Accord requires commercial banks 
that engage in significant trading activity $(10 \%$ of total assets on a world-wide consolidated basis or $\$ 1$ billion or more) to set aside additional capital to cover the market risks inherent in their trading accounts. ${ }^{6}$ The amendment allows sophisticated banks to use their own internally developed value-at-risk models to determine adequate capital requirements. Banks can meet this new capital requirement with standard forms of capital (Tier 1 or Tier 2) or by issuing a new form of capital, called Tier 3 capital. It consists of less permanent, more fluid forms of capital (such as short-term subordinated debt) retained to cover losses on trading activities and other market-related risks.

Since the early 1990s, the Basle Accord capital requirements have become the standard for regulators throughout the industrialized world. The methodology applies to all financial intermediaries in the EU and was implemented in the member via the Own Funds Directive (1989), the Solvency Ratio Directive (1989), and the Capital Adequacy Directive (1993). In the United States, the regulation came into force in 1992 and was extended to the insurance and securities industries. Today, the Basle Committee on Banking Supervision claims that more than one hundred national regulators throughout the world have adopted its risk-based capital requirements.

Besides the Basle Accord risk-based capital requirements, US banks are subject to an additional domestic capital requirement. The Federal Deposit Insurance Corporation (FDIC), the Office of the Comptroller of the Currency (OCC), and the Federal Reserve Board are jointly responsible for monitoring and regulating the US financial services industry. They require banks and other depository institutions to maintain a minimum leverage ratio of Tier 1 capital to total average assets. The minimum ratio depends on the institution's rating under the regulatory

\footnotetext{
${ }^{6}$ See Bank for International Settlements (1996).
} 
$\mathrm{CAMELS}^{7}$ rating system. The minimum Tier 1 leverage ratio for institutions with a CAMEL rating of 1 is $3 \%$. For all other institutions the ratio is $4 \%$. Furthermore, the 1991 Federal Deposit Insurance Corporation Improvement Act (FDICIA) added to the existing capital adequacy guidelines a uniform framework for prompt corrective regulatory action. Under this framework, each institution falls into one of five regulatory capital categories based primarily on the three capital measures: Tier 1 leverage, Total risk-based, and Tier 1 risk-based capital. The five categories and the minimum capital levels are presented in Table 2.

[Insert Table 2 about here]

The Prompt Corrective Action provisions of FDICIA require that regulatory bodies apply progressively more stringent restrictions on an institution's operations as its capital category falls. These restrictions range from limiting or prohibiting the institution's ability to engage in certain activities, such as making acquisitions, branching, or entering new lines of business (undercapitalized), to restricting asset growth (significantly undercapitalized), to the appointment of a receiver or conservator of the institution's net assets (critically undercapitalized). Even institutions falling in the adequately capitalized category (the minimum regulatory requirements) could be subject to some discretionary restrictions by regulators. ${ }^{8}$ Thus, although not legally obliged, US banks have a strong incentive to maintain their capital levels in the well-capitalized category in order to avoid constant regulatory scrutiny and restrictions on their operations.

\footnotetext{
${ }^{7}$ The CAMELS rating derives its name from the various components that are rated: capital adequacy, assets quality, management, earnings, liquidity, and sensitivity to interest rates.

${ }^{8}$ Adequately and well-capitalised institutions could be restricted from paying dividends or management fees to controlling persons if this would result in undercapitalization.
} 
Over time, limitations of the 1988 Basle Accord have become apparent. First, it is argued that the regulatory measure of bank risk as stipulated by the risk weights can differ substantially from the actual risk the bank faces. Banks today derive a large portion of their income not from their traditional deposit-taking and lending activities but from trading activities and service fees, which exposes them to significant market risk. However, as currently written, the risk-based capital standards account primarily for credit risk. A second criticism of the Accord has to do with the unchanging $8 \%$ minimum capital requirement - the so-called "rules-based" approach. ${ }^{9}$ The argument is that risk is not constant throughout the business cycle. Thus, it may be preferable to require banks to keep more than the $8 \%$ minimum in the contractionary phase of the business cycle to guard against the more risky operating environment usually associated with an economic downturn. To address these limitations, the Basle Committee on Banking Supervision has spent the past several years developing the Basle II Capital Accord. ${ }^{10}$ This new regulation is meant to expand the 1988 Accord in four main areas: (1) A bank's minimum capital ratio will be calculated on the sum of the bank's credit, market, and operational risks. This expanded definition of risk reflects the type of business in which banks now engage and the business environment in which banks operate. (2) Banks will be able to use their own market risk models, such as value-at-risk (VAR), for setting capital requirements. That is, instead of using "rulesbased" approach to determine adequate bank capital, a more flexible, "risk-focused" approach that relies on modern portfolio theory. (3) The internal management procedure banks use to decide on how much capital to hold will be subject to supervisory review, after which banks could be required to hold capital beyond the regulatory minimum in some circumstances. (4)

\footnotetext{
${ }^{9}$ See IMF (1998).

${ }^{10}$ See Bank for International Settlements (2001).
} 
There will be increased bank disclosure standards in terms of bank capital and risk exposure to strengthen the position of market participants in encouraging banks to hold more capital. The Basle II Capital Accord is expected to come into effect at year-end 2006 as the committee has been exploring a number of important issues since the draft of the new accord was released in January 2001.

\section{CURRENT EVIDENCE ON US AND EUROPEAN BANK M\&AS}

Research on bank M\&As has been conducted following one of two distinct approaches. The first one uses market data and the event study methodology to evaluate the stock market reaction to merger announcements. As such, the studies that follow this approach address the critical question of whether bank M\&As create shareholder wealth. The second approach uses accounting data to determine why banks merge and whether consolidation leads to changes in efficiency, costs, revenues, or profits. ${ }^{11}$

Regarding the first approach, most of the empirical research on abnormal returns in bank mergers uses US data whereas only a few studies use European data. ${ }^{12}$ Although some studies investigate where the value gains come from, neither of them has examined the role of regulatory capital in the market valuation of bank M\&As. The US evidence suggests that bank M\&As over the past 20 years have, on average, been a zero-sum exercise. Target bank shareholders earn significantly positive abnormal returns in the period around the merger announcement at the expense of acquiring bank shareholders. The overall value created is either slightly positive, but not statistically significant, or non-existent suggesting that, on average, there is a redistribution of

\footnotetext{
${ }^{11}$ See Rhoades (1994) for an excellent discussion of the two approaches.

${ }^{12}$ The only study that uses both, US and non-US data to examine the wealth effects of bank mergers, is that of DeLong (2003a).
} 
wealth. Results to this effect are consistently reported by a wide variety of studies using various samples, time periods, and levels of analysis. ${ }^{13}$ However, those mergers that do create value seem to involve efficient acquirers, high degree of geographic overlap between the merging banks, narrow activity focus, high potential for cost reductions, and cash or conditional-stock method of payment. The European evidence on abnormal returns in bank mergers is limited ( $\operatorname{Rad}$ and Van Beek 1999, Cybbo-Ottone and Murgia 2000, and Beitel and Schiereck 2001). To some extent this scarcity of research reflects the methodological difficulties in studying the European market. For example, only a small minority of banks in Europe has actively traded. The general picture that emerges is that bank M\&As result in significant value creation for target bank's shareholders and no significant value destruction for acquiring bank's shareholders. Thus, on aggregate European bank M\&As create significant shareholder wealth. However, Beitel and Schiereck (2001) observe an interesting phenomenon - more recent European bank M\&As announced in the period 1998 to 2000 have, on aggregate, destroyed value. Target bank's shareholders still earn significantly positive abnormal results, but acquiring bank's shareholders experience significantly negative market reaction. These results were more pronounced for large acquirers and those involved in cross-border transactions. These findings are somewhat more consistent with the US evidence. A possible explanation is that as capital markets in Europe develop and become increasingly important as a source of financing (which is the case in the USA), the pattern of stock market reaction to merger announcements is becoming more similar to the US experience. With respect to sources of value creation, Cybbo-Ottone and Murgia (2000) obtain similar results to those

\footnotetext{
${ }^{13}$ See for example Hannan and Wolken (1989), Hawawini and Swary (1990), Cornett and Tehranian (1992), Houston and Ryngaert (1994), Madura and Wiant (1994), Siems (1996), Pilloff (1996), DeLong (2001), Houston, James and Ryngaert (2001), DeLong (2003b). Rhoades (1994) and Pilloff and Santomero (1998) review the extensive literature on the US experience.
} 
reported for the US market. They find that domestic and focused (bank-to-bank) deals create more shareholder value than cross-border and diversifying transactions. From the latter group, only bancassuarance deals were found to create value, whereas mergers with investment banks were found to destroy value.

The second approach to studying bank mergers and acquisitions uses accounting data to determine what drives bank mergers and whether consolidation leads to changes in efficiency, costs, revenues, or profits. ${ }^{14}$ The typical methodology in most of the studies that use accounting data is to compare balance sheet-based indicators of performance of the merging banks (e.g., ROA, ROE, etc.) before and after the merger to see if there is a change in performance around the time of the merger activity. ${ }^{15}$ Here is appears that, on average, bank M\&As do not significantly improve the performance of the merging entities. Alternatively, some studies use stochastic frontier methodologies to determine whether M\&As in the banking industry improve the efficiency of the consolidating entities. ${ }^{16}$ Again, most of the studies report that, on average, bank

\footnotetext{
${ }^{14}$ Proponents of using accounting data argue that they measure actual performance rather than market expectations and are, therefore, likely to be a more reliable indicator of merger-related gains. Furthermore, accounting performance can be directly measured and the data used are both readily available and well understood. A major shortcoming of this approach, however, is the fact that accounting numbers, although designed to measure actual performance, can be inaccurate in an economic sense. They are based on historical figures and ignore current market values. Furthermore, accounting measures of performance can be manipulated and are dependent on the accounting standards in use. Thus, using this approach to studying cross-border mergers and acquisitions should take into consideration any potential differences in accounting standards.

${ }^{15}$ See Shrinivasan (1992), Shrinivasan and Wall (1992), Linder and Crane (1993), Rhoades (1993), Spindt and Tarhan (1993), Vander Vennet (1996), Chamberlain (1998), Calomiris and Karceski (1998).

${ }^{16}$ See Berger and Humphrey (1992), DeYoung (1993), Akhavein, Berger and Humphrey (1997), DeYoung (1997), Berger (1998), Resti (1998), Focarelli, Panetta, \& Salleo (2000).
} 
mergers do not improve significantly either the cost or profit efficiency of the merging entities. Finally, a few studies compare the characteristics of the merging banks to those of a control group of non-merging banks to determine which banks are more likely to engage in merger activity, either as acquirers or as targets. For example, Hannan and Rhoades (1987), Moore (1997) and Wheelock and Wilson (2000) identify the characteristics that make individual US banks more likely to become takeover targets. They find that banks with low capital are relatively more attractive as acquisition targets. Hannan and Rhoades (1987) suggest that, other things equal, higher capitalized banks require a greater payment, which makes them less attractive as acquisition targets. However, Wheelock and Wilson (2000) propose that lower capitalized banks are closer to the point of becoming insolvent and are thus more likely to exit the industry by being acquired. Finally, O'Keefe (1996) finds that target banks' equity capitalization rates are higher, on average, than those of their acquirers but significantly lower than those of their nonacquired peers. However, the study fails to find a significant relationship between the equity capitalization rate of a bank and the probability of it being acquired. Furthermore, the author investigates the characteristics of the banks that make them more likely to acquire other banks. acquiring banks seemed to have lower equity capitalization rates than their targets and nonacquiring peers, and lower capitalized banks were more likely to acquire other banks. However, the factors that seemed to be the most significant determinants of merger activity for both acquirers and targets were size, liquidity, loan concentration, and management quality. In general, large, efficient, and well-run banks acquired much smaller, less efficient, and poorly managed institutions. The only study, which examines the role of regulatory bank capital in mergers and acquisitions, is that of Hannan and Pilloff (2004). The authors test what they call the "excess regulatory capital" argument. Under this hypothesis, banks with levels of regulatory capital in excess of the required minimum will engage in more acquisitions as bidders than banks for which 
the regulatory capital level is binding. The authors argue that there are at least two reasons for that. First, banks with no excess regulatory capital wishing to engage in a certain acquisition may be deterred to do so by regulators, because the merger might cause the combined entity to violate minimum capital adequacy standards. However, targets with levels of regulatory capital in excess of the required minimum are less likely to violate minimum capital standards and, thus, more likely to acquire other banks. Second, banks with excess regulatory capital may free some of this capital and boost returns to shareholders. This may, in turn, increase the valuation of the company, which could facilitate acquisition activity. The authors test the excess regulatory capital hypothesis, using panel data analysis, on a sample of 38 large bank holding companies that existed in the period 1998-2002. They estimate the relationship between the regulatory capital level of a bank and subsequent merger activity (the number of acquisitions that the bank holding company engages in). They fail to find a significant relationship between the two and thus conclude that the level of regulatory bank capital is not a significant determinant of merger activity. However, their study is limited in two aspects. First, there are at least two reasons that the results of this study are not of general relevance: First, the analysis is limited to the largest bank holding companies in the USA (with total assets of at least $\$ 15$ billion). Second, the study does not address the question of whether banks that engage in merger activity either as acquirers or as targets are higher or lower capitalized than those that do not engage in merger activity. In this paper we attempt to overcome these limitations by focusing on a larger sample and by distinguishing acquirers and targets. Thus, based on the excess regulatory capital hypothesis we expect that both acquirers and targets have relatively high capital level (to increase the probability of regulatory approval) and that acquirers focus on targets with higher capital levels (as these exhibit inefficiently low ROE). 


\section{SAMPLE SELECTION}

The data used in this study are collected from five different sources: Zephyr, an electronic database of global mergers and acquisitions from 1997 to 2004 from the Thompson Financial Data Company; DataStream, an electronic database of company information including stock market quotations also from the Thompson Financial Data Company; Edgar, a web-based database of US listed companies' filings with the Securities and Exchange Commission (SEC); Bankscope, an electronic database of bank financial statement data. This last source is supplemented with the authors' own collection of annual reports of banks.

In a first step, a preliminary list of US and European, domestic as well as cross-border bank M\&As announced in the period 1997 to 2003 is created by searching Zephyr. In order for a merger to be included at least one of the parties - acquirer or target - needs to be a bank, the other being a financial services firm. Furthermore, only quoted companies are considered so that the stock market reaction to merger announcements can be analyzed. Finally, only deals resulting in the acquirer controlling the majority stake in the target $(50 \%$ or more of the common stock outstanding) are considered. Note that the European sub-sample is restricted to the European Union plus Switzerland and Norway. ${ }^{17}$ This procedure yields 216 transactions, of which 59 are European and 157 are US mergers. In a second step, we require the following data for each merger transaction: (1) The date of the merger announcement - available in the Zephyr database. (2) Stock market prices adjusted for dividends and capital changes for both acquirer and target for

\footnotetext{
${ }^{17}$ The markets of Central and Eastern Europe were excluded because the banking sector and capital markets in this region are still underdeveloped and acquisition activity in the time period studied is to a large extent determined by privatisation programs. Most importantly, banks in this region are subject to domestic capital adequacy requirements different from those established by the Basle Accord and different for every country, which would have made comparisons of capital levels meaningless.
} 
approximately one year prior to the merger announcement. These data are collected from DataStream. Mergers for which neither or just one of the parties had a stock quotation in DataStream or for which the data were insufficient are discarded. (3) Tier 1 and Total risk-based capital ratios for both acquirer and target for the year immediately prior to the merger announcement. For the US banks capital ratios are collected from Edgar. For the European banks the annual reports are searched manually. Again, deals for which capital ratios are available for neither or just one of the parties are discarded. (4) Total assets of both acquirer and target for the year immediately preceding the one in which the merger announcement was made. These are collected in the same way as the previous item. These four requirements considerably reduce the size of the sample. Full data is available only for 105 deals - 84 US and 21 European mergers. It should be noted, however, that this sample size is considerably larger than that of most other studies on abnormal returns in bank mergers. The distribution of the mergers over time and countries is presented in Table 3 .

\section{[Insert Table 3 about here]}

The providers of the Zephyr database claim that it contains the complete populations of M\&As since 1997. As such a comparison of the preliminary and the final sample can reveal selection biases due to our data requirements. With 100 out of 105 , the majority of the transactions in the final sample involve partners from the same country. This was also true for the preliminary sample where only 7 out of the 216 mergers initially identified are cross-border transactions. Thus, among listed banks this seems to be a general feature of bank mergers during the time period rather than a sample bias. Another feature of the final sample is that not all European countries are equally represented. In fact, some markets are not represented at all. 
Again, this was also the case in the preliminary sample. For example, Austria, Portugal, Finland, and Luxembourg do not have any bank mergers among listed partners in the time period studied and the Netherlands, Ireland, and Spain have just one transaction each, which are not included in the final sample due to lack of either stock market or capital ratios data. The most active European markets are those of the United Kingdom, Italy, and Germany, which is also the case in the final sample. Thus, despite its small size, the European sub-sample is generally representative of the population of European bank mergers among listed partners in the time period examined.

The distribution over time suggests that most of the merger activity is concentrated in the second half of the sample period from 2000 to 2003 with only four transactions taking place from 1997 to 1999 . This is generally consistent with the theoretical literature and empirical findings that merger activity tends to occur in waves. A possible explanation for the increase in merger activity in the 2000 to 2003 period is the introduction of the Euro for the European market and the relaxation of the interstate branching and universal banking restrictions for the US market. One striking difference between the US and European merger sample should be mentioned at the outset: European acquirers and targets tend to be considerably larger than their US counterparts. The mean (median) size of European acquirers and targets is $\$ 157$ bn ( $\$ 114$ bn) and $\$ 44$ bn $(\$$ $2.6 \mathrm{bn}$ ), respectively. In the US, mean (median) acquirer and target size amounts to only $\$ 22 \mathrm{bn}$ (\$ $4.4 \mathrm{bn})$ and $\$ 4.7$ bn $(\$ 0.5 \mathrm{bn})$, respectively. These findings are consistent with other studies on abnormal returns in bank mergers ${ }^{18}$ and are most likely driven by the fact that the majority of banks in Europe are closely held, state-owned, or co-operative societies and that only a small portion of very large banks have actively traded stocks.

\footnotetext{
${ }^{18}$ Cybo-Ottone and Murgia (2000) compare the average size of the banks in their sample of European mergers with those of selected US studies and find almost identical results. Similar findings are also reported by DeLong (2003a).
} 
In addition to the main sample of merger transactions, we collect a control sample of banks not engaged in any M\&A activity during the sample period. For inclusion in this control sample a bank has to satisfy four criteria: First, the bank has to be listed. Note that this requirement does not affect substantially the composition of the US sub-sample as the majority of US banks including even relatively small institutions are listed. However, as only large European banks have stock market quotations this requirement results in a European sub-sample consisting of companies much larger, on average, than the banks in the US sub-sample. However, this feature of the control sample is desirable since the European banks in the core sample of mergers are also much larger than their US counterparts. Therefore, this requirement assures that the control sample is structured similarly to the core sample of deals and that the European subsample of non-acquired banks is directly comparable to the sub-sample of European targets. Second, we require that the bank be a resident of one of the countries included in the study. Banks from countries not represented in my core sample, but nevertheless covered in the study, are included in the control sample as well. Third, we require that the bank has not been engaged in any M\&A activity during the sample period either as acquirer or as target. To make sure this is the case, each bank included in the sample is checked in the Zephyr database for any acquisition record. Banks, which engage in mergers that are only announced but not subsequently completed, are not included in the sample. Finally, the bank must have at least two consecutive years of total assets and capital ratios available in the sample period. All dollar values of total assets are adjusted by the CPI to 2003 values. Similarly, the consecutive observations of Tier 1 and Total capital ratios were averaged to produce the mean values for the period. These control sample data are collected from Bankscope for the European banks and from the Edgar database for the US banks. Overall, for our control sample we are able to identify 195 banks of which 92 are European and 103 are US banks. 


\section{METHODOLOGY AND RESULTS}

\section{Difference in capital ratios}

As a first step in the analysis we perform mean-difference tests to compare the pre-merger regulatory capital levels of the target banks with those of their acquirers and non-acquired peers. If the excess regulator capital hypothesis is correct, we would expect to find: (1) If acquirers select their targets with the objective to benefit from the reduction in excess capital, targets should maintain, on average, higher pre-merger regulatory capital levels than their acquirers. (2) If concerns regarding regulatory intervention matter, than targets and acquirers should have, on average, higher pre-merger capital levels than their non-merging peers.

First we compare the mean capital ratios and total assets in the year before the merger of the target banks with those of their acquirers. The capital ratios are approximately normally distributed as indicated by a comparison of the mean and median values. Thus, the standard t-test for the difference between the means of two populations is used. Total assets, however, have strongly skewed distributions and therefore a non-parametric z-test is more appropriate. The results reported in Table 4 suggest the following: First, acquiring banks are significantly larger in size than their targets. This is true for the total sample as well as for the US and European subsamples. ${ }^{19}$ This finding is consistent with the empirical and theoretical literature on mergers and acquisitions in general. Broadly speaking, the size of a company is an approximate indicator of its value, and consequently, a smaller firm is cheaper and easier to purchase. Conversely, larger firms generally have more funds and access to more financing options than smaller companies, and it is therefore easier for them to afford an acquisition. The results suggest that the banking

\footnotetext{
${ }^{19}$ Paired two-sample tests show even more significant results but as paired tests can only be conducted for acquirers versus targets, they are not reported in the table.
} 
industry is not an exception to this principle. Second, target banks have, on average, significantly higher regulatory capital ratios than their acquirers. This finding is robust for the total sample as well as for the US sub-sample but only with respect to Tier 1 capital for the European subsample. These findings are again consistent with our expectations and with results reported in other empirical studies. Thus, for example, Hannan and Pilloff (2004) report that "banking organizations that were acquired by the bank holding companies in our sample tended to have larger capital ratios than their acquirers" (p. 25). Similarly, O'Keefe (1996) reports that the target banks' equity capitalization rates in his sample are, on average, higher than those of their acquirers. Although the authors do not explicitly investigate the issue, Hannan and Pilloff suggest that this result may simply stem from the fact that larger banking organizations tend to have lower capital ratios. A possible reason for this could be that larger companies often have more diversified portfolios and, thus, they are less risky and need to hold less excess capital. As target banks, however, are often of smaller size than their acquirers, they may have, on average, higher capital ratios than their acquirers. To see if such a relationship exists we explicitly test for the correlation between total assets and regulatory capital ratios and find that, although negative in sign as suggested by Hannan and Pilloff, the correlation coefficients of -0.23 for total assets and Tier 1 capital ratios and -0.18 for total assets and Total capital ratios are insignificant. Therefore, the regulatory capital levels of the banks in the sample are essentially independent of the size of the companies. Overall our analysis suggests that target banks have, on average, significantly higher capital ratios than their acquirers, and this differential is not accounted for by the smaller size of the acquired institutions.

Second, we compare the mean capital ratios and total assets of target and acquiring banks with those of their non-merging counterparts. Looking at the total sample of all banks we find that acquirers are significantly larger than non-merging banks. Their slightly lower capital ratios 
are, however, not found to be significantly different from non-merging bank's ratios. Target banks are not significantly different in size than non-merged banks. ${ }^{20}$ With respect to the capital ratios, we find for the total sample and the US sub-sample that target banks have, on average, significantly higher pre-merger capital ratios than their non-acquired counterparts. The finding is robust and holds for both Tier 1 and Total capital ratios. For the European sub-sample, however, although positive in sign, the difference between the capital ratios of acquired and non-acquired institutions is not statistically significant. Nevertheless, the results are generally consistent with our expectations that target banks have, on average, higher pre-merger regulatory capital levels than their non-acquired peers.

Finally, it is interesting to compare the regulatory capital levels of the US acquirers and targets to those of their European counterparts. Such a comparison is important for two reasons: First, US banks have a strong incentive to maintain their regulatory capital levels in the wellcapitalized category (Tier 1 capital $\geq 6 \%$ and Total capital $\geq 10 \%$ ) in order to avoid constant regulatory scrutiny and restrictions on their operations. As mentioned earlier, a bank may be disallowed to engage in a merger if the capital level of the combined entity threatens to fall short of minimum regulatory requirements. Therefore, it is interesting to see whether the Prompt Corrective Action provisions of the Federal Deposit Insurance Corporation are effective in raising the capital levels of US financial institutions. Second, and more important to the analysis in this paper, if the Prompt Corrective Action provisions do affect the capital holdings of US banks, the potential for reducing the capital levels of acquired institutions may be, other things equal, lower for the US companies than for their European counterparts. Therefore, if this turns out to be the case, a more meaningful measure of this potential would be the excess regulatory

\footnotetext{
${ }^{20}$ Similar results are reported by Hannan and Rhoades (1987) and Wheelock and Wilson (2004).
} 
capital of a bank - the capital above and over the regulatory requirements - rather than its actual capital ratios. The results suggest that European banks are, on average, significantly larger in size than their US counterparts. The finding holds for acquirers, targets, and non-merging banks. However, as suggested previously in the paper, this result is most probably attributable to the composition of the sample regarding listed banks and is not likely to be of general significance. Furthermore, US banks have significantly higher capital ratios than their European counterparts. The finding holds for both Tier 1 and total capital ratios as well as for acquirers, targets, and nonmerging banks. It thus appears that the Prompt Corrective Action provisions of the Federal Deposit Insurance Corporation are effective in raising the capital levels of US banks.

\section{[Insert Table 4 about here]}

To summarize, the results of the mean-difference tests suggest that target banks are, on average, significantly better capitalized than their acquirers and non-acquired peers. However, the results for the European sub-sample suggest that European targets do not differ significantly either in size or in capital from their non-acquired peers. Finally, comparisons of the capital levels of US and European banks suggest that the PCA provisions of the FDIC are effective in raising the capital levels of US institutions. Therefore, more meaningful comparisons of the capital levels of US and European banks could be made with the excess capital holdings of the banks rather than with their actual capital ratios. In the next section we will therefore focus on the role of excess regulatory capital when investigating the market valuation of bank M\&As. 


\section{Market valuation of bank mergers and acquisitions}

To study the impact of regulatory capital on the market valuation of bank M\&As, we employ standard event study methodology. Note that the market model parameters were estimated over a period of 200 days ranging from -240 to -41 days relative to the announcement day. The return on the DataStream bank sector index for the respective country was used as the benchmark. The advantage of using DataStream's own index is that it is constructed in the same way for each country, so that differences in index composition do not affect the estimated coefficients. Furthermore, a bank sector index, rather than a total market index, is used in order to derive better estimates for the abnormal returns. The use of a total market index has the disadvantage of under- or overestimating the abnormal returns in cases of industry-specific developments, such as changes in regulatory requirements or a major restructuring, affecting the sector more than the market as a whole. However, most studies on abnormal returns in bank mergers, using both a bank sector index and a total market index to estimate abnormal returns, report that the results are not statistically different from each other (e.g. Cybo-Ottone and Murgia 2000). Cumulative average abnormal returns (CAARs) are calculated over several event windows to better evaluate the market reaction before and after the merger announcement as well as in the periods surrounding it. Furthermore, CAARs are calculated for the US and European sub-samples in addition to the total sample to examine any potential differences in the pattern of stock market reaction to merger announcements between the two markets.

The results of the event studies are reported in Table 5. Panel A of Table 5 presents the cumulative average abnormal returns for the total sample of target banks as well as for the US and European sub-samples. Panel B reports the corresponding results for the sample of acquiring banks. Consistent with the majority of studies on abnormal returns in bank mergers, target bank shareholders earn significantly positive abnormal returns in any of the event windows analyzed. 
This is true for both the US and European sub-samples, as well as for the total sample of target banks. Consistent with other studies we find that target bank shareholders earn, on average, positive and highly significant abnormal returns in the period around the merger announcement. As such bank M\&As in both the US and European markets create significant wealth for target bank shareholders. ${ }^{21}$ Looking at the total sample of bank mergers, acquiring bank shareholders earn, on average, negative abnormal returns in any of the event windows analyzed. Furthermore, the results are statistically significant in most of the time intervals examined. Similarly, the results for the US acquirers are negative in most of the event windows analyzed and significant in particular in immediately surrounding the announcement day. Again, our results for US acquirers are consistent with those reported in other studies on abnormal returns in bank mergers. ${ }^{22} \mathrm{We}$ can therefore confirm that US bank M\&As destroy value for acquiring bank shareholders. Turning to the European acquirers, the results are mixed. Acquiring banks' shareholders earn significantly positive abnormal returns on the days immediately surrounding the announcement. At the same

${ }^{21}$ Regarding European bank mergers, Cybo-Ottone and Murgia (2000) and Beitel and Schiereck (2001) find for the $[-1 ;+1]$ interval significant CAARs of $12.93 \%$ and $12.39 \%$, respectively, which are similar to our CAAR of $14.74 \%$. For the larger event window of $[-20 ;+20]$, the same studies find significant CAARs of $15.30 \%$ and $16 \%$, respectively, which compare well with our result of 17.68\%. For US targets Siems (1996) and DeLong (2003a) find significant average abnormal returns $(A A R)$ on the day of the merger announcement of $12 \%$ and $15.40 \%$, respectively, which are comparable to our result of $13.87 \%$. The former also reports a CAAR of $12.81 \%$ in the $[-1 ; 0]$ event window, which is not considerably different from the result of this study (15.27\%). Finally, our results are consistent with those of DeLong (2003a), who finds that, upon the announcement, non-US targets earn, on average, less that their US counterparts.

${ }^{22}$ For comparison, Siems (1996) finds a significantly negative $C A A R$ of $-1.96 \%$ in the $[-1 ;+1]$ time interval, which is similar to our result of $-1.50 \%$. Hawawini and Swary (1990) report a negative and significant $C A A R$ of $-1.70 \%$ in the first five days after the merger announcement. The corresponding result of this study is $-1.18 \%$. 
time, however, acquiring banks' shareholders earn, on average, significantly negative abnormal returns after the announcement. A possible explanation for this finding is that as the consummation of the deals proceedes, possible implementation unexpected difficulties become clear causing the market to revise its initial expectations. A natural candidate for these implementation difficulties is the European legal system, which offers more protection to employees. Rad and Van Beek (1999) point out that this makes it more difficult to lay off redundant employees and realize cost cuts and operational synergies immediately after the completion of a merger. Overall, our results are consistent with those of other studies with a European focus in that acquiring bank shareholders earn positive or non-negative abnormal returns in the period immediately surrounding the announcement of the deal. ${ }^{23}$ This is in sharp contrast with the US evidence, where acquiring bank shareholders are found to experience significantly negative abnormal returns around the merger announcement. Finally, when comparing target and acquirer returns our results are generally consistent with DeLong (2003a), who finds that, upon the announcement, non-US bank mergers differ from US bank mergers in that non-US acquirers earn more and non-US targets earn less than their US counterparts. We find that, on the day of the announcement, European targets earn an average abnormal return of $12.08 \%$ compared with $13.87 \%$ for the US targets. This lower abnormal return could also be driven by the regulatory impediments in Europe discussed above. European acquirers, however, earn a positive and significant average abnormal return of $0.76 \%$ on the announcement day, whereas their US counterparts earn a significantly negative average abnormal return of $-0.79 \%$.

\footnotetext{
${ }^{23}$ See Cybo-Ottone and Murgia (2000) and Beitel and Schiereck (2001) who provide similar, yet more clear-cut results.
} 
[Insert Table 5 about here]

\section{Regulatory capital and value creation}

To investigate the relationship between regulatory bank capital and value creation we follow Hannan and Pilloff (2004), and focus on excess regulatory capital rather than actual capital. They define excess capital as the "difference between the actual capital ratios less some critical level based on regulatory requirements or standards". This critical level is given as the $4 \%$ and $8 \%$ of Tier 1 and Total capital requirements for European banks and the $6 \%$ and 10\% capital requirements for US banks. If US banks are, in effect, required to hold more capital than their European counterparts - the results of the mean-difference tests strongly point to this conclusion the former may have a lower capacity, other things equal, to reduce their capital levels and those of the acquired institutions than the latter. Therefore, the measure of excess capital puts this capacity on a common scale and allows for more meaningful comparisons of the capital levels of US and European banks. Table 6 summarizes the results of our analysis into the differences in abnormal returns between banks with high versus low excess capital. ${ }^{24}$ In particular, we compare mergers where the target (acquirer) belongs to the top $25 \%$ fractile with respect to excess capital to those mergers where the target (acquirer) belongs to the bottom $25 \%$ fractile. Note that once we have classified a merger as belonging to the top or bottom fractile based on the target's (acquirer's) excess capital, we look at both the acquirer and the target's value effects. Finally, we perform the analyses separately for Tier 1 and Total capital ratios.

\footnotetext{
${ }^{24}$ In contrast to Table 5, Table 6 reports results for selected time periods only. We focus on the short-run surrounding the announcement up to a time interval of $[-1,+1]$ and a longer-run after the announcement represented by the time intervals $[0,+20]$ and $[0,+40]$.
} 
The results for targets reported in Panel A and B suggest that mergers involving targets with high levels of excess regulatory capital create more value for target banks' shareholders around the time of the merger announcement. The difference in short- and longer-term abnormal returns between the two portfolios is positive and highly significant for both Tier 1 and Total capital ratios. Clearly, high-capital targets are valued more by the market than their lowercapitalized counterparts. Looking now at the acquirer results in the same panels reveals that there is no difference in abnormal returns for acquirers bidding for high versus low capital targets. Taken together the results in Panel A and B suggest that mergers with high excess capital targets create more value but that this value accrues fully to the target's shareholders. This is consistent with the first part of the excess regulatory capital hypothesis outlined above.

\section{[Insert Table 6 about here]}

The analysis of Panel C and D of Table 6 allows us to investigate this aspect by focusing on mergers with high versus low excess capital acquirers. Here the role of excess capital seems to be less relevant. There is some support that in the longer-run low-capitalized acquirers loose more than high-capitalized acquirers. Furthermore, targets that are acquired by high-capitalized acquirers seem to have a higher value effect than targets acquired by low-capitalized acquirers. This effect is especially strong when total excess capital of the acquirer is considered. It thus appears that the potential of the acquiring bank to reduce the capital holdings of the target institution - as suggested initially by the results of Panels A and B - does not play a role in the market valuation of target bank's shares around the time of the merger announcement. Instead, a possible explanation for the results so far is that target banks' abnormal returns may simply reflect the acquisition premiums that would be received by target banks' shareholders in case the 
merger is completed. However, mergers involving high capital partners are less likely to violate, post-acquisition, regulatory capital adequacy requirements and thus, other things equal, are more likely to be approved by regulators. Therefore, it is possible that target banks' abnormal returns and to a lesser extend also acquirer banks' abnormal returns - adjust to reflect this probability.

There is, however, another way to investigate the question of whether the potential of the acquirers to reduce the capital holdings of the targets plays a role in the market valuation of bank M\&As. We therefore focus in Panel $\mathrm{E}$ and $\mathrm{F}$ relative capitalization of the target banks rather than on their absolute capital levels. Relative capitalization is defined as the capital holdings of the target banks divided by those of their acquirers. Bidding banks that acquire targets with high relative capitalization ratios have a higher potential to reduce the capital levels of the acquired institutions. ${ }^{25}$ The results in Panels E and F show no significant differences in abnormal returns for the target bank but the expected positive but only marginally significant difference i.e. in at announcement for the acquiring bank. This is consistent with our interpretation that the target banks' abnormal return reflects an acquisition premium. It seems that the potential of the acquiring bank to reduce the excess capital holdings of the target institution is (marginally) valued by the market and this upside potential accrues to acquiring banks' shareholders. This finding makes sense, as it is the acquiring bank's shareholders (the potential new owners of the target) who will benefit from the reduction of the excess capital holdings of the acquired institution and reap the associated boost in returns.

Finally, in order to analyze the joint impact of a number of explanatory variables we perform multiple OLS regressions of the abnormal returns of each bank on the following set of

\footnotetext{
${ }^{25}$ Using the difference between the excess capital level of the target and that of its acquirer as an alternative measure of this potential, we obtain very similar results to those when using the relative capital ratio.
} 
explanatory variables: The bank's Tier 1 excess capital, the bank's Tier 1 excess capital relative to that of its merger partner, the bank's size given by the natural logarithm of its total assets, and the bank's size relative to that of its merger partner also given in natural logarithm. To allow for possible differences between US and European mergers, we also include a dummy coded 1 if one of the merging banks is US-based.

Looking first at the target banks confirms the results of the previous analyses. Target banks' shareholders earn higher abnormal returns, the higher the target's excess capital. This can reflect the probability of the merger being approved by regulators. The negative coefficient on the relative excess capital proxies, i.e. in the longer term, furthermore confirms the argument that targets that are acquired by better-capitalized acquirers seem to have a higher value effect than targets acquired by less well-capitalized acquirers. Consider a given target. On the one hand, if this target is acquired by a highly capitalized acquirer, its relative excess capital proxy is low and its abnormal return is high. On the other hand, if this target is acquired by a lowly capitalized acquirer, its relative excess capital proxy is high and its abnormal return is low. Thus, there exists an inverse relationship between the target's abnormal return and its relative excess capital. Finally, the size of the target or its geographic location does not influence its abnormal return. The insignificance of the US dummy indicates that the differences in abnormal returns between the US and Europe reported in Table 5 can be fully explained by differences in excess regulatory capital.

[Insert Table 7 about here]

Turning now to the abnormal returns of acquiring banks' shareholders reveals that these are negatively and significantly related to the size of the acquiring institution. A possible 
explanation for this finding is the existence of economies of scale in banking. Other things equal, smaller acquirers have a higher potential to realize economies of scale and, thus, they are likely to benefit more from an acquisition. For example, the acquiring institution may use the target bank's distribution network and customer base to sell its own products and services. Furthermore, it may be able spread its managerial know-how on a larger scale. By contrast, a very large acquirer may even experience diseconomies of scale. Results to this effect are reported in Beitel and Schiereck (2001). The authors find that the 10 largest acquirers in their sample of European mergers show significantly negative abnormal returns around the announcement day, whereas the small and medium-sized acquirers experienced positive market reaction. In addition, our results suggest that the smaller the target bank relative to its acquirer, the higher the abnormal returns for acquiring banks' shareholders. Again, a possible explanation for this finding is that by acquiring smaller banks, which are presumably less efficient and sophisticated, acquiring banks can benefit by improving the efficiency of the target. Secondly, the dummy variable indicating the market of the acquirer carries a negative and significant coefficient. This finding is, consistent with the event study results suggesting that European acquirers earn significantly higher abnormal returns on the day of the merger announcement than their US counterparts. In fact, as Panel B of Table 5, indicates, European acquirers earn, on average, positive and significant abnormal returns, whereas US acquirers experience significantly negative market reaction. Finally, the conclusions based Table 6 that the market positively values the potential of the acquirers to reduce the capital holdings of the targets and that better capitalized acquirers earn higher abnormal returns cannot be confirmed here. The coefficients of the excess as well as relative excess capital measures are insignificant. 


\section{CONCLUSIONS}

By examining 105 US and European bank mergers announced between 1997 and 2003 we can reveal several interesting effects of the target's and acquirer's regulatory capital. First, looking at the differences in regulatory capital shows that on average i.e. US targets maintained significantly higher levels of regulatory bank capital than their acquirers and non-acquired peers. Furthermore, US banks maintain, on average, significantly higher regulatory capital levels than their European counterparts. This finding indicates that the Prompt Corrective Action provisions of the FDIC are effective in raising the capital levels of US financial institutions. Second, the results of the analyses into the relationship between shareholder value creation and excess regulatory capital unambiguously point to one conclusion - capital is valuable in bank mergers. Mergers involving high-capital targets create more shareholders value, and targets that are acquired by better-capitalized acquirers seem to have a higher value effect than targets acquired by less well-capitalized acquirers.

The results of this paper might appear to contradict those reported in other studies. Hannan and Rhoades (1987), O’Keefe (1996), Moore (1997), and Wheelock and Wilson (2000) have all found that banks with low equity capitalization rates (capital-to-assets ratios) are relatively more attractive as acquisition targets. However, there is not necessarily a contradiction. As stipulated by the Basle I Accord, regulatory capital ratios are designed to reflect the riskiness of financial institutions - it is the risk-weighted assets in the denominator of the ratio, rather than average total assets. Therefore, a more risk-averse institution having its portfolio invested in less risky assets, will have lower risk-adjusted assets and, consequently, higher regulatory capital ratios than an otherwise similar, but less risk-averse, bank. Furthermore, the more risk-averse a bank is, the higher its risk-based capital ratios will be relative to its equity-to-assets ratio. However, as less risky assets usually yield lower returns, such risk-averse institutions may have 
problems providing adequate returns to shareholders. It is not surprising, therefore, that the same studies mentioned above also find that target banks have considerably lower ROAs and ROEs than their acquirers and non-acquired peers. Therefore, high regulatory capital targets may be penalized by the market for being excessively risk-averse and not taking advantage of the opportunity to invest in more profitable assets. The argument can be extended even further. In an effort to provide competitive returns to shareholders, such institutions may be tempted to reduce their equity capitalization rates rather than investing in more risky and profitable assets. However, as their regulatory capital ratios are much higher than their equity capitalization rates, and in all probability, much higher than regulatory requirements, those banks may be willing and able to maintain lower equity ratios than their competitors. This argument may help explain why target banks have, on average, higher regulatory capital ratios but at the same time lower equity capitalization rates than other, more efficient institutions. Is there any evidence to suggest that target banks are generally more risk-averse than their non-acquired counterparts? There is. For example, O’Keefe (1996) reports that target banks have significantly higher proportions of their assets in cash balances and significantly lower proportions in loans and securities than their peers. Similarly, Moore (1997) finds that the probability of acquisition is significantly and negatively related to the bank's ratio of loans to total assets. Therefore, although seemingly in contrast, our results and those of other studies actually point to the same conclusion - target banks are excessively risk-averse and fail to provide adequate returns to shareholders. High capital ratios, low equity rates, and inadequate ROEs may be just different symptoms of the same problem - excessive risk-aversion. 


\section{REFERENCES}

Akhavein, J.D., Berger, A.N., Humphrey, D.B., 1997, The Effects of Megamergers on Efficiency and Prices: Evidence from a Bank Profit Function. Review of Industrial Organization 12, 95-139.

Bank for International Settlements, 1989, International Convergence of Capital Measurement and Capital Standards (Bank for International Settlements, Basle).

Bank for International Settlements, 1996, Overview of the Amendment to the Capital Accord to Incorporate Market Risks (Bank for International Settlements, Basle).

Bank for International Settlements, 2001, The New Basle Capital Accord: An Explanatory Note (Bank for International Settlements, Basle).

Beitel, P., Schiereck, D., 2001, Value Creation at the Ongoing Consolidation of the European Banking Market, Institute for Mergers and Acquisitions Working Paper No. 05/01.

Berger, A.N., 1998, The Efficiency Effects of Bank Mergers and Acquisitions: A Preliminary Look at the 1990s Data. In: Amihud, Y., Miller, G. (Eds.), Bank Mergers and Acquisitions, Kluwer Academic Publishers, Boston, pp. 79-111.

Berger, A.N., Humphrey, D.B., 1992, Megamergers in Banking and the Use of Cost Efficiency as an Antitrust Defense, Antitrust Bulletin 37, 541-600.

Berger, A.N., Humphrey, D.B., 1997, Efficiency of Financial Institutions: International Survey and Directions for Future Research, European Journal of Operational Research 98, 175212.

Berger, A.N., Kashyap, A.K., Scalise, J.M., 1995, The Transformation of the US Banking Industry: What a Long, Strange Trip It's Been, Brookings Papers on Economic Activity 2, 55-218. 
Calomiris, C.W., Karceski, J., 1998, Is the Bank Merger Wave of the 1990s Efficient? Lessons Learned from Nine Case Studies (The AEI Press, Washington).

Chamberlain, S.L., 1998, The Effect of Bank Ownership Changes on Subsidiary-Level Earnings. In: Amihud, Y., Miller, G. (Eds.), Bank Mergers and Acquisitions, Kluwer Academic Publishers, Boston, pp. 137-172.

Cornett, M.M., Tehranian, H., 1992, Changes in Corporate Performance Associated with Bank Acquisitions, Journal of Financial Economics 3, 211-234.

Cybo-Ottone, A., Murgia, M., 2000, Mergers and Shareholder Wealth in European Banking, Journal of Banking and Finance 24, 831-859.

DeLong, G.L., 2001, Stockholder Gains from Focusing versus Diversifying Bank Mergers, Journal of Financial Economics 59, 221-252.

DeLong, G.L., 2003a, The Announcement Effects of US versus Non-US Bank Mergers: Do They Differ?, The Journal of Financial Research 26, 487-500.

DeLong, G.L., 2003b, Does Long-Term Performance of Mergers Match Market Expectations? Evidence from the US Banking Industry, Financial Management 32, 5-25.

DeYoung, R., 1993, Determinants of Cost Efficiencies in Bank Mergers, Office of the Comptroller of the Currency - Economic and Policy Analysis Working Paper 93-1.

DeYoung, R., 1997, Bank Mergers, X-Efficiency, and the Market for Corporate Control, Managerial Finance 23, 32-47.

European Central Bank, 2000, Mergers and Acquisitions Involving the EU Banking Industry Facts and Implications (European Central Bank, Frankfurt).

Focarelli, D., Panetta, F., Salleo C., 2002, Why do Banks Merge?, Journal of Money, Credit, and Banking 34, 1047-1066.

Group of Ten, 2001, Report on Consolidation in the Financial Sector (OECD, Paris). 
Hannan, T.H., Pilloff, S.J., 2004, Will the Proposed Application of Basel II in the United States Encourage Increased Bank Merger Activity? Evidence from Past Merger Activity, Board of Governors of the Federal Reserve System - Finance and Economics Discussion Series 2004-13.

Hannan, T.H., Rhoades, S.A., 1987, Acquisition Targets and Motives: The Case of the Banking Industry, Review of Economics \& Statistics, 69, 67-75.

Hannan, T.H., Wolken, J.D., 1989, Returns to Bidders and Targets in the Acquisition Process: Evidence from the Banking Industry, Journal of Financial Services Research 3, 5-16.

Hawawini, G., Swary, I., 1990, Mergers and Acquisitions in the US banking industry; Evidence from the Capital Markets (Elsevier Science Publishers, Amsterdam).

Houston, J.F., Ryngaert, M.D., 1994, The Overall Gains from Large Bank Mergers, Journal of Banking and Finance 18, 1155-1176.

Houston, J.F., James, C.M., Ryngaert, M.D., 2001, Where Do Merger Gains Come from? Bank Mergers from the Perspective of Insiders and Outsiders, Journal of Financial Economics $60,285-331$.

International Monetary Fund, 1998, International Capital Markets: Developments, Prospects, and Key Policy Issues (International Monetary Fund, Washington DC, pp. 138-41).

Linder, J.C., Crane, D.B., 1992, Bank Mergers: Integration and Profitability, Journal of Financial Services Research 7, 35-55.

Madura, J., Wiant, K.J., 1994, Long-Term Valuation Effects of Bank Acquisitions, Journal of Banking and Finance 18, 1135-1154.

Moore, R.R., 1997, Bank Acquisition Determinants: Implications for Small Business Credit, Federal Reserve Bank of Dallas -Financial Industry Studies Working Paper 97-2. 
O’Keefe, J.P., 1996, Banking Industry Consolidation: Financial Attributes of Merging Banks, FDIC Banking Review 9 (1).

Piloff, S.J., 1996, Performance Changes and Shareholder Wealth Creation Associated with Mergers of Publicly Traded Banking Institutions, Journal of Money, Credit and Banking 28, 294-310.

Piloff, S.J., Santomero, A.M., 1998, The Value Effects of Bank Mergers and Acquisitions. In: Amihud, Y., Miller, G. (Eds.), Bank Mergers and Acquisitions, Kluwer Academic Publishers, Boston.

Rad, A.T., Van Beek, L., 1999, Market Valuation of European Bank Mergers, European Management Journal 17, 532-539.

Resti, A., 1998, Regulation Can Foster Mergers, Can Mergers Foster Efficiency? The Italian Case, Journal of Economics and Business 50, 157-169.

Rhoades, S.A., 1993, Efficiency Effects of Horizontal (in-Market) Bank Mergers, Journal of Banking and Finance 17, 411-422.

Rhoades, S.A., 1994, A Summary of Merger Performance Studies in Banking, 1980-1993, and an Assessment of the Operating Performance and Event Study Methodologies, The Federal Reserve Bulletin 80, 588-590.

Siems, T.F., 1996, Bank Mergers and Shareholder Wealth: Evidence from 1995's Megamerger Deals, Federal Reserve Bank of Dallas - Financial Industry Studies, August, 1-12.

Spindt, P.A., Tarhan, V., 1993, The Impact of Mergers on Bank Operating Performance, Center for Financial and Policy Studies Working Paper 93-22.

Srinivasan, A., 1992, Are there Cost Savings from Bank Mergers?, Federal Reserve Bank of Atlanta - Economic Review, March/April, 17-28. 
Srinivasan, A., Wall, L.D., 1992, Cost Savings Associated with Bank Mergers, Federal Reserve Bank of Atlanta Working Paper 92-2.

Vander Vennet, R., 1996, The Effect of Mergers and Acquisitions on the Efficiency and Profitability of EC Credit Institutions, Journal of Banking and Finance 20, 1531-1558.

Wheelock, D.C., Wilson, P.W., 2000, Why Do Banks Disappear? The Determinants of US Bank Failures and Acquisitions, Review of Economics and Statistics 82, 127-138. 
Table 1: International definitions of bank capital provided by the Basle I Accord Type of Capital

Countries

\section{Tier 1 (Core Capital)}

A. Equity capital (including retained earnings)

All

B. Discosed reserves

All

C. Some forms of preferred stock

United States Less Goodwill

Tier 2 (Supplementary Capital)

A. General provisions/loan-loss reserves

All

B. Undisclosed reserves

C. Revaluation reserves

Japan, Germany

D. Hybrid (debt-equity) instruments

1. Long-term preferred shares

All

2. Titres participatifs, titres subordonnes

Canada

3. Genusscheine

France

4. Perpetual debts

Germany

5. Mandatory convertible debt instruments

United Kingdom

United States

Source:Bardos (1988: pp.26-34) 
Table 2: Capital thresholds and bank classification under Prompt Corrective Action (PCA).

\begin{tabular}{|c|c|c|c|}
\hline Category & $\begin{array}{c}\text { Total risk-based } \\
\text { Ratio } \\
\end{array}$ & $\begin{array}{c}\text { Tier } 1 \text { risk-based } \\
\text { Ratio } \\
\end{array}$ & $\begin{array}{c}\text { Tier } 1 \text { leverage } \\
\text { Ratio } \\
\end{array}$ \\
\hline Well capitalized & $\geq 10 \%$ & $\geq 6 \%$ & $\geq 5 \%$ \\
\hline Adequately capitalized & $\geq 8 \%$ & $\geq 4 \%$ & $\geq * 4 \%$ \\
\hline Undercapitalised & $<8 \%$ & $<4 \%$ & $<* 4 \%$ \\
\hline Significantly undercapitalised & $<6 \%$ & $<3 \%$ & $<3 \%$ \\
\hline Critically undercapitalised & Tangible equity ratio $\leq * * 2 \%$ & & \\
\hline
\end{tabular}

.for institutions with a rating of one under the regulatory CAMELS rating system \%3 *

The tangible equity ratio is equal to tangible equity divided by total tangible assets **

Source: Bondt and Prast (2000). 
Table 3: Geographic and time distribution of bank merger sample

\begin{tabular}{|c|c|c|c|c|c|c|c|c|c|c|c|c|c|c|c|c|}
\hline & \multicolumn{2}{|c|}{1997} & \multicolumn{2}{|c|}{1998} & \multicolumn{2}{|c|}{1999} & \multicolumn{2}{|c|}{2000} & \multicolumn{2}{|c|}{2001} & \multicolumn{2}{|c|}{2002} & \multicolumn{2}{|l|}{2003} & \multicolumn{2}{|c|}{ Total } \\
\hline & $\mathrm{B}$ & $\mathrm{T}$ & $\mathrm{B}$ & $\mathrm{T}$ & $\mathrm{B}$ & $\mathrm{T}$ & $\mathrm{B}$ & $\mathrm{T}$ & $\mathrm{B}$ & $\mathrm{T}$ & $\mathrm{B}$ & $\mathrm{T}$ & B & $\mathrm{T}$ & $\mathrm{B}$ & $\mathrm{T}$ \\
\hline Belgium & & & & & & & $1 B$ & & & & & & & & $1 \mathrm{~B}$ & \\
\hline Denmark & & & & & & & & & $1 \mathrm{~B}$ & $2 \mathrm{~T}$ & $1 \mathrm{~B}$ & $1 \mathrm{~T}$ & & & $2 B$ & $3 \mathrm{~T}$ \\
\hline France & & & & & & & & & & & $1 B$ & $1 \mathrm{~T}$ & & & $1 \mathrm{~B}$ & $1 \mathrm{~T}$ \\
\hline Germany & $1 B$ & $1 \mathrm{~T}$ & & & & & & & $1 \mathrm{~B}$ & $1 \mathrm{~T}$ & $1 B$ & $1 \mathrm{~T}$ & & & $3 B$ & $3 \mathrm{~T}$ \\
\hline Greece & & & & & & & $1 B$ & $1 \mathrm{~T}$ & & & & & $1 B$ & $1 \mathrm{~T}$ & $2 B$ & $2 \mathrm{~T}$ \\
\hline Italy & & & & & & & & & & & $4 B$ & $4 \mathrm{~T}$ & $1 B$ & $1 \mathrm{~T}$ & $5 B$ & $5 T$ \\
\hline Norway & & & & & & & & & & & $1 B$ & $1 \mathrm{~T}$ & & & $1 \mathrm{~B}$ & $1 \mathrm{~T}$ \\
\hline Sweden & & & & & & & & & & & & & & & $2 B$ & $1 \mathrm{~T}$ \\
\hline UK & $1 B$ & $1 \mathrm{~T}$ & & $1 \mathrm{~T}$ & $1 B$ & $1 \mathrm{~T}$ & $1 \mathrm{~B}$ & $1 \mathrm{~T}$ & $2 \mathrm{~B}$ & $1 \mathrm{~T}$ & $1 \mathrm{~B}$ & & & $1 \mathrm{~T}$ & $4 B$ & $5 \mathrm{~T}$ \\
\hline USA & & & $1 \mathrm{~B}$ & & & & $38 \mathrm{~B}$ & 39T & $8 B$ & $8 \mathrm{~T}$ & $20 B$ & $21 \mathrm{~T}$ & 17B & $16 \mathrm{~T}$ & $84 \mathrm{~B}$ & $84 \mathrm{~T}$ \\
\hline Total & 2B & $2 T$ & $1 B$ & $1 T$ & $1 B$ & $1 \mathrm{~T}$ & 41B & 41T & $12 B$ & $12 T$ & 29B & 29T & $19 B$ & 19T & 105B & $105 T$ \\
\hline
\end{tabular}

$\mathrm{B}=$ bidder; $\mathrm{T}=$ target; domestic mergers = 100; cross-border mergers $=5$. The cross-border deals account for the differences in the number of bidders and targets for some of the countries. 
Table 4: Differences in size and capital between banks

Panel A: Size and capital by type of bank

\begin{tabular}{|c|c|c|c|c|c|c|c|}
\hline \multirow[b]{2}{*}{ bank type } & \multicolumn{2}{|c|}{ total assets ( $\$$ million) } & \multicolumn{2}{|c|}{ Tier 1 capital ratio $(\%)$} & \multicolumn{2}{|c|}{ total capital ratio (\%) } & \multirow{2}{*}{$\begin{array}{l}\text { Obser- } \\
\text { vations }\end{array}$} \\
\hline & Mean & Median & Mean & Median & Mean & Median & \\
\hline \multicolumn{8}{|l|}{ all banks } \\
\hline acquirers & $49,063.72$ & $5,813.27$ & 11.59 & 10.10 & 13.59 & 12.07 & 105 \\
\hline targets & $12,633.03$ & 622.76 & 14.26 & 11.96 & 15.83 & 13.92 & 105 \\
\hline non-merging & $14,902.27$ & $1,186.37$ & 11.60 & 10.56 & 13.46 & 12.23 & 195 \\
\hline \multicolumn{8}{|l|}{ US banks } \\
\hline acquirers & $22,202.00$ & $4,357.38$ & 12.34 & 10.45 & 14.09 & 12.43 & 84 \\
\hline targets & $4,710.90$ & 486.18 & 15.23 & 12.56 & 16.63 & 14.15 & 84 \\
\hline non-merging & $5,058.96$ & 427.50 & 13.25 & 11.77 & 14.66 & 12.88 & 103 \\
\hline \multicolumn{8}{|c|}{ European banks } \\
\hline acquirers & $156,510.56$ & $113,529.84$ & 8.62 & 8.10 & 11.60 & 10.96 & 21 \\
\hline targets & $44,321.55$ & $2,567.82$ & 10.37 & 10.51 & 12.63 & 12.79 & 21 \\
\hline non-merging & $25,922.49$ & $7,734.62$ & 9.76 & 8.81 & 12.11 & 11.75 & 92 \\
\hline
\end{tabular}

Panel B: Testing differences in mean

\begin{tabular}{|c|c|c|c|c|c|c|}
\hline \multirow[b]{2}{*}{ comparison } & \multicolumn{2}{|c|}{ total assets } & \multicolumn{2}{|c|}{ Tier 1 capital ratio } & \multicolumn{2}{|c|}{ total capital ratio } \\
\hline & test statistic & p-value & test statistic & p-value & test statistic & $\mathrm{p}$-value \\
\hline \multicolumn{7}{|c|}{ bidder versus target banks } \\
\hline all & 3.041 & 0.001 & -2.882 & 0.002 & -2.544 & 0.006 \\
\hline US & 2.685 & 0.004 & -2.659 & 0.004 & -2.429 & 0.008 \\
\hline European & 2.371 & 0.009 & -1.692 & 0.049 & -0.986 & 0.165 \\
\hline \multicolumn{7}{|c|}{ target versus non-merging banks } \\
\hline all & -0.409 & 0.341 & 3.251 & 0.001 & 3.029 & 0.001 \\
\hline US & -0.097 & 0.461 & 1.955 & 0.026 & 1.975 & 0.025 \\
\hline European & 0.894 & 0.186 & 0.784 & 0.219 & 0.724 & 0.237 \\
\hline \multicolumn{7}{|c|}{ bidder versus non-merging banks } \\
\hline all & 2.969 & 0.001 & -0.016 & 0.494 & 0.221 & 0.413 \\
\hline US & 2.569 & 0.005 & -1.126 & 0.131 & -0.728 & 0.234 \\
\hline European & 3.012 & 0.001 & -1.321 & 0.098 & -0.585 & 0.282 \\
\hline \multicolumn{7}{|c|}{ US versus European banks } \\
\hline acquirers & -3.094 & 0.001 & 3.688 & 0.000 & 2.443 & 0.009 \\
\hline targets & -1.988 & 0.023 & 4.371 & 0.000 & 3.726 & 0.000 \\
\hline non-merging & -3.299 & 0.000 & 5.597 & 0.000 & 4.281 & 0.000 \\
\hline
\end{tabular}

In panel A, the dollar values of total assets are adjusted by the CPI to 2003 values. In panel B, note that for total assets, a nonparametric z-test is applied. For capital ratios a t-test with unequal variances is applied. P-values refer to one-sided tests. 
Table 5: Event study results

\begin{tabular}{|c|c|c|c|c|c|c|}
\hline \multirow[b]{2}{*}{ event window } & \multicolumn{2}{|c|}{ all banks } & \multicolumn{2}{|c|}{ US banks } & \multicolumn{2}{|c|}{ European banks } \\
\hline & CAAR (\%) & t-statistic & CAAR (\%) & t-statistic & CAAR (\%) & t-statistic \\
\hline \multicolumn{7}{|c|}{ Panel A: Cumulative average abnormal returns (CAARs) of targets } \\
\hline \multicolumn{7}{|c|}{ on the event day } \\
\hline $\mathrm{AAR}[0]$ & 13.51 * & 57.77 & 13.87 * & 52.09 & 12.08 * & 30.89 \\
\hline \multicolumn{7}{|c|}{ surrounding the event day } \\
\hline$[-1,+1]$ & 19.06 * & 47.07 & $20.15 *$ & 43.69 & 14.74 * & 21.76 \\
\hline$[-5,+5]$ & 21.61 * & 27.87 & 23.22 * & 26.30 & 15.20 * & 11.72 \\
\hline$[-10,+10]$ & 24.41 * & 22.78 & 26.12 * & 21.41 & 17.59 * & 9.81 \\
\hline$[-20,+20]$ & 25.81 * & 17.24 & 27.84 * & 16.33 & 17.68 * & 7.06 \\
\hline$[-40,+40]$ & 29.88 * & 14.20 & 33.32 * & 13.91 & 16.11 * & 4.57 \\
\hline \multicolumn{7}{|c|}{ before the event day } \\
\hline$[-1,0]$ & 15.11 * & 45.69 & 15.27 * & 40.56 & 14.48 * & 26.17 \\
\hline$[-5,0]$ & 16.98 * & 29.64 & 17.24 * & 26.44 & 15.93 * & 16.63 \\
\hline$[-10,0]$ & 19.31 * & 24.90 & 19.66 * & 22.26 & 17.93 * & 13.82 \\
\hline$[-20,0]$ & 20.40 * & 19.04 & 21.00 * & 17.21 & 18.01 * & 10.05 \\
\hline$[-40,0]$ & 22.53 * & 15.05 & 24.42 * & 14.32 & 14.99 * & 5.98 \\
\hline \multicolumn{7}{|c|}{ after the event day } \\
\hline$[0,+1]$ & 17.46 * & 52.81 & 18.74 * & 49.78 & 12.35 * & 22.32 \\
\hline$[0,+5]$ & 18.15 * & 31.68 & 19.85 * & 30.44 & 11.35 * & 11.85 \\
\hline$[0,+10]$ & 18.61 * & 23.99 & 20.32 * & 23.02 & 11.75 * & 9.05 \\
\hline$[0,+20]$ & 18.92 * & 17.65 & 20.71 * & 16.98 & 11.76 * & 6.56 \\
\hline$[0,+40]$ & 20.86 * & 13.93 & 22.77 * & 13.36 & 13.20 * & 5.27 \\
\hline \multicolumn{7}{|c|}{ Panel B: Cumulative average abnormal returns (CAARs) of acquirers } \\
\hline \multicolumn{7}{|c|}{ on the event day } \\
\hline AAR[0] & -0.48 * & -2.22 & -0.79 * & -3.19 & 0.76 ** & 2.10 \\
\hline \multicolumn{7}{|c|}{ surrounding the event day } \\
\hline$[-1,+1]$ & -0.99 * & -2.63 & $-1.50 *$ & -3.48 & $1.04 * \star$ & 1.67 \\
\hline$[-5,+5]$ & -1.70 * & -2.37 & $-1.88 * *$ & -2.29 & -0.99 & -0.83 \\
\hline$[-10,+10]$ & $-2.40 *$ & -2.41 & $-2.05 * *$ & -1.80 & $-3.77 * *$ & -2.29 \\
\hline$[-20,+20]$ & -2.29 & -1.64 & -1.29 & -0.81 & $-6.26 *$ & -2.72 \\
\hline$[-40,+40]$ & -1.10 & -0.56 & 0.14 & 0.06 & $-6.06 * *$ & -1.87 \\
\hline \multicolumn{7}{|c|}{ before the event day } \\
\hline$[-1,0]$ & $-0.69 * *$ & -2.25 & $-1.13 *$ & -3.23 & 1.08 ** & 2.12 \\
\hline$[-5,0]$ & -1.18 ** & -2.22 & $-1.49 *$ & -2.45 & 0.05 & 0.06 \\
\hline$[-10,0]$ & -1.64 ** & -2.28 & -1.88 ** & -2.28 & -0.69 & -0.58 \\
\hline$[-20,0]$ & -1.40 & -1.41 & -1.49 & -1.31 & -1.04 & -0.63 \\
\hline$[-40,0]$ & -0.79 & -0.56 & -0.84 & -0.53 & -0.58 & -0.25 \\
\hline \multicolumn{7}{|c|}{ after the event day } \\
\hline$[0,+1]$ & $-0.78 *$ & -2.55 & -1.16 * & -3.30 & 0.72 & 1.42 \\
\hline$[0,+5]$ & $-1.00 * \star$ & -1.89 & -1.18 ** & -1.95 & -0.29 & -0.33 \\
\hline$[0,+10]$ & -1.24 ** & -1.72 & -0.97 & -1.17 & -2.33 ** & -1.95 \\
\hline$[0,+20]$ & -1.37 & -1.38 & -0.59 & -0.52 & -4.47 * & -2.71 \\
\hline$[0,+40]$ & -0.80 & -0.58 & 0.18 & 0.11 & -4.72 ** & -2.05 \\
\hline
\end{tabular}

** Indicates results significant at the $5 \%$ level. * Indicates results significant at the 1\% level. 


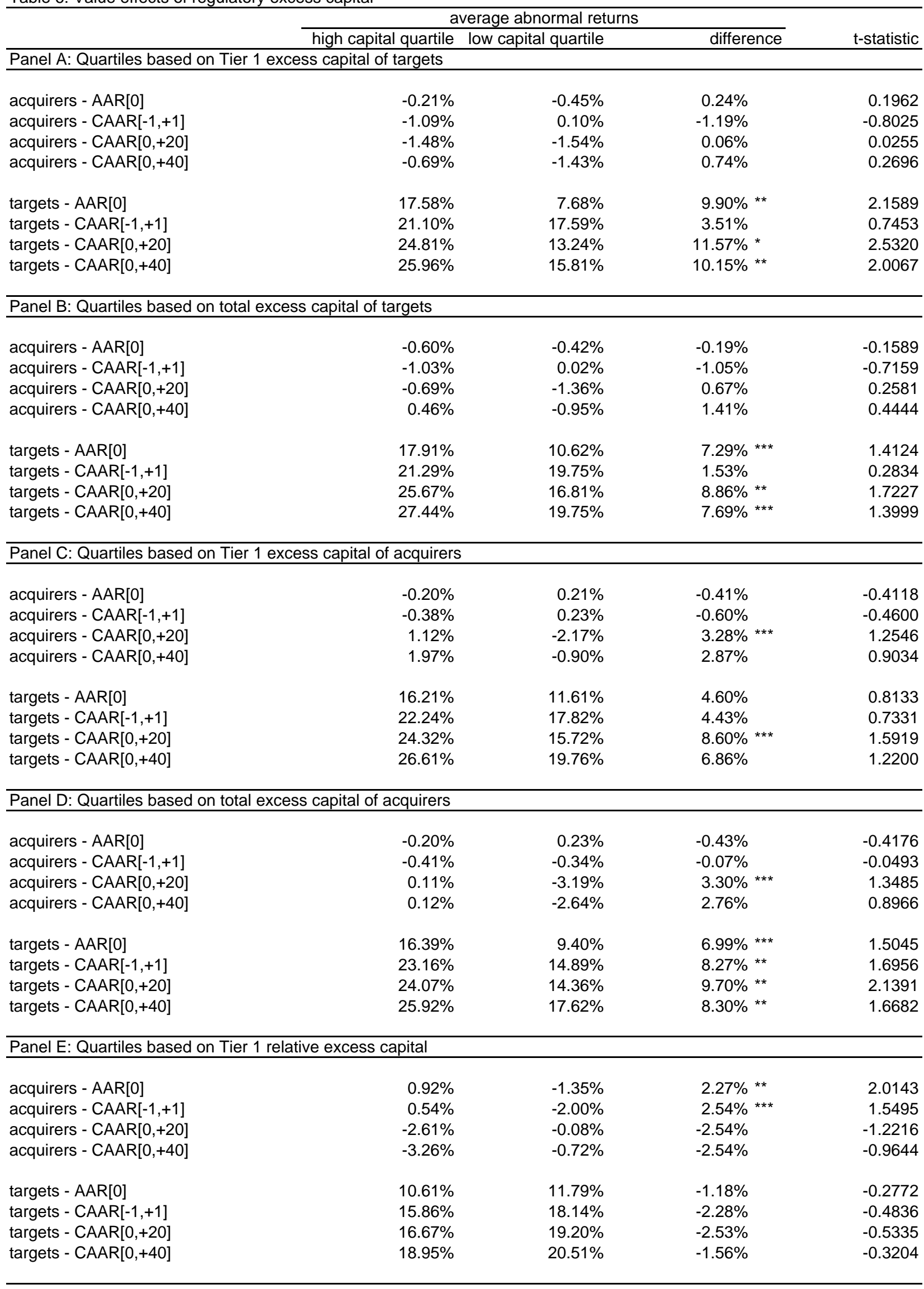


Table 6 (conti.)

Panel F: Quartiles based on total relative excess capital

\begin{tabular}{|c|c|c|c|c|}
\hline acquirers - AAR[0] & $0.66 \%$ & $-0.53 \%$ & $1.19 \%$ *** & 1.2561 \\
\hline acquirers - CAAR $[-1,+1]$ & $0.05 \%$ & $-0.44 \%$ & $0.49 \%$ & 0.5145 \\
\hline acquirers - CAAR $[0,+20]$ & $-2.38 \%$ & $-0.07 \%$ & $-2.31 \%$ & -1.1022 \\
\hline acquirers - CAAR $[0,+40]$ & $-3.90 \%$ & $0.44 \%$ & $-4.34 \% * \star \star$ & -1.5190 \\
\hline targets - AAR[0] & $11.11 \%$ & $11.84 \%$ & $-0.73 \%$ & -0.175 \\
\hline targets - CAAR $[-1,+1]$ & $16.26 \%$ & $17.55 \%$ & $-1.29 \%$ & -0.2901 \\
\hline targets - CAAR $[0,+20]$ & $17.31 \%$ & $19.02 \%$ & $-1.71 \%$ & -0.3689 \\
\hline targets - CAAR $[0,+40]$ & $19.19 \%$ & $20.91 \%$ & $-1.73 \%$ & -0.3469 \\
\hline
\end{tabular}

Panel G: Quartiles based on bidder's asset size

\begin{tabular}{|c|c|c|c|c|}
\hline acquirers - AAR[0] & $-0.81 \%$ & $-0.79 \%$ & $-0.02 \%$ & -0.0197 \\
\hline acquirers - CAAR $[-1,+1]$ & $-0.35 \%$ & $-0.12 \%$ & $-0.23 \%$ & -0.1715 \\
\hline acquirers - CAAR $[0,+20]$ & $-4.04 \%$ & $-0.10 \%$ & $-3.94 \% * *$ & -1.7230 \\
\hline acquirers - CAAR $[0,+40]$ & $-3.49 \%$ & $0.63 \%$ & $-4.13 \% * \star \star$ & -1.5198 \\
\hline targets - AAR[0] & $10.17 \%$ & $11.69 \%$ & $-1.52 \%$ & -0.2830 \\
\hline targets - CAAR $[-1,+1]$ & $16.52 \%$ & $17.77 \%$ & $-1.25 \%$ & -0.2272 \\
\hline targets - CAAR $[0,+20]$ & $11.85 \%$ & $20.28 \%$ & $-8.43 \%$ *** & -1.4750 \\
\hline targets - CAAR $[0,+40]$ & $15.54 \%$ & $21.40 \%$ & $-5.87 \%$ & -0.9949 \\
\hline \multicolumn{5}{|c|}{ Panel H: Quartiles based on target's asset size } \\
\hline acquirers - AAR[0] & $-2.05 \%$ & $0.12 \%$ & $-2.17 \% * *$ & -1.6960 \\
\hline acquirers - CAAR $[-1,+1]$ & $-2.23 \%$ & $-0.57 \%$ & $-1.66 \%$ & -0.9094 \\
\hline acquirers - CAAR $[0,+20]$ & $-4.42 \%$ & $-1.25 \%$ & $-3.18 \%$ & -1.2051 \\
\hline acquirers - CAAR $[0,+40]$ & $-2.62 \%$ & $-0.65 \%$ & $-1.98 \%$ & -0.6146 \\
\hline targets - AAR[0] & $9.61 \%$ & $15.86 \%$ & $-6.26 \%$ *** & -1.3211 \\
\hline targets - CAAR $[-1,+1]$ & $11.32 \%$ & $22.95 \%$ & $-11.63 \%$ * & -2.4754 \\
\hline targets - CAAR $[0,+20]$ & $11.99 \%$ & $25.00 \%$ & $-13.01 \%$ * & -2.4641 \\
\hline targets - CAAR $[0,+40]$ & $15.87 \%$ & $26.42 \%$ & $-10.54 \%$ ** & -1.8018 \\
\hline
\end{tabular}

Note: The high and low capital quartiles are the top and bottom $25 \%$ fractiles. This leads to 26 observations for each fractile. $\star \star \star, ~ * \star$, and * indicate significance at the $10 \%, 5 \%$, and $1 \%$ level respectively based on a one-sided t-test for differences in mean assuming unequal variances. Tier 1 relative excess capital is defined as the Tier 1 excess capital of the target bank divided by the Tier 1 excess capital of the bidder bank. The corresponding definition applies to total relative excess capital. 


\begin{tabular}{|c|c|c|c|c|c|c|c|c|}
\hline dependent variable & AR[0] & AR[0] & $\mathrm{AR}[-1,+1]$ & $\mathrm{AR}[-1,+1]$ & $A R[0,+20]$ & $A R[0,+20]$ & $\mathrm{AR}[0,+40]$ & $\mathrm{AR}[0,+40]$ \\
\hline \multirow[t]{2}{*}{ constant } & 0.106 & 0.137 & 0.172 & 0.205 & 0.277 & $0.327 * \star *$ & 0.224 & 0.274 \\
\hline & 0.543 & 0.734 & 0.878 & 1.091 & 1.409 & 1.740 & 1.057 & 1.350 \\
\hline \multirow[t]{2}{*}{ Tier 1 excess capital of target } & $0.007 * \star *$ & & $0.006 * * *$ & & 0.008 ** & & 0.008 *** & \\
\hline & 1.719 & & 1.650 & & 2.161 & & 1.850 & \\
\hline Total excess capital of target & & $\begin{array}{l}0.006 * * * \\
1.659\end{array}$ & & $\begin{array}{l}0.006 \\
1.617\end{array}$ & & $\begin{array}{l}0.008 \text { ** } \\
2.061\end{array}$ & & $\begin{array}{l}0.007 \text { *** } \\
1.669\end{array}$ \\
\hline Tier 1 excess relative capital & $\begin{array}{l}-0.005 \\
-1.130\end{array}$ & & $\begin{array}{l}-0.007 \\
-1.764\end{array}$ & & $\begin{array}{l}-0.008 \text { ** } \\
-2.029\end{array}$ & & $\begin{array}{l}-0.008^{* \star *} \\
-1.760\end{array}$ & \\
\hline \multirow[t]{2}{*}{ Total relative excess capital } & & -0.003 & & -0.006 & & $-0.007 * \star *$ & & -0.006 \\
\hline & & -0.851 & & -1.472 & & -1.748 & & -1.352 \\
\hline \multirow[t]{2}{*}{ LN(total assets of target) } & -0.002 & -0.004 & -0.007 & -0.009 & -0.014 & -0.016 & -0.010 & -0.012 \\
\hline & -0.219 & -0.338 & -0.649 & -0.799 & -1.256 & -1.496 & -0.832 & -1.040 \\
\hline \multirow[t]{2}{*}{ LN(total assets of target/acquirer) } & -0.011 & -0.009 & $-0.028 * \star$ & $-0.025 * \star$ & -0.011 & -0.008 & -0.016 & -0.013 \\
\hline & -0.853 & -0.728 & -2.087 & -1.949 & -0.849 & -0.625 & -1.136 & -0.918 \\
\hline \multirow[t]{2}{*}{ US merger dummy } & -0.007 & -0.004 & 0.031 & 0.035 & 0.041 & 0.045 & 0.054 & 0.058 \\
\hline & -0.159 & -0.078 & 0.669 & 0.744 & 0.860 & 0.959 & 1.057 & 1.131 \\
\hline adjusted $\mathrm{R}^{2}$ & 0.000 & 0.000 & 0.055 & 0.049 & 0.081 & 0.074 & 0.053 & 0.044 \\
\hline dependent variable & AR[0] & AR[0] & $\mathrm{AR}[-1,+1]$ & AR $[-1,+1]$ & $A R[0,+20]$ & $A R[0,+20]$ & $A R[0,+40]$ & $\mathrm{AR}[0,+40]$ \\
\hline \multirow[t]{2}{*}{ constant } & 0.062 & 0.065 & 0.033 & 0.038 & 0.093 & 0.107 & 0.131 & 0.134 \\
\hline & 1.443 & 1.571 & 0.568 & 0.496 & 1.025 & 1.243 & 1.112 & 1.197 \\
\hline \multirow[t]{2}{*}{ Tier 1 excess capital of acquirer } & 0.000 & & 0.001 & & 0.000 & & -0.001 & \\
\hline & -0.229 & & 0.575 & & 0.227 & & -0.516 & \\
\hline \multirow[t]{2}{*}{ Total excess capital of acquirer } & & 0.000 & & 0.001 & & 0.000 & & -0.001 \\
\hline & & -0.466 & & 0.585 & & 0.122 & & -0.616 \\
\hline \multirow[t]{2}{*}{ Tier 1 excess relative capital } & 0.000 & & 0.000 & & -0.002 & & -0.002 & \\
\hline & 0.425 & & 0.361 & & -1.478 & & -1.087 & \\
\hline \multirow[t]{2}{*}{ Total relative excess capital } & & 0.000 & & 0.000 & & $-0.002 * \star * *$ & & -0.002 \\
\hline & & 0.372 & & 0.107 & & -1.753 & & -1.190 \\
\hline \multirow[t]{2}{*}{ LN(total assets of acquirer) } & $-0.004 * * *$ & $-0.004^{* * *}$ & -0.002 & -0.002 & $-0.009 * * \star$ & -0.010 ** & $-0.011 * * *$ & $-0.011 * \star * *$ \\
\hline & -1.719 & -1.807 & -0.638 & -0.736 & -1.769 & -1.996 & -1.679 & -1.772 \\
\hline \multirow[t]{2}{*}{ LN(total assets of target/acquirer) } & $-0.008 *$ & $-0.008 *$ & -0.004 & -0.005 & -0.009 & -0.009 & -0.010 & -0.010 \\
\hline & -2.894 & -2.902 & -1.220 & -1.278 & -1.552 & -1.568 & -1.371 & -1.362 \\
\hline \multirow[t]{2}{*}{ US merger dummy } & $-0.021 * *$ & $-0.022 * *$ & $-0.030 * *$ & $-0.029 * \star$ & 0.025 & 0.025 & 0.034 & 0.033 \\
\hline & -2.098 & -2.130 & -2.167 & -2.119 & 1.166 & 0.238 & 1.214 & 1.188 \\
\hline adjusted $R^{2}$ & 0.069 & 0.071 & 0.013 & 0.013 & 0.051 & 0.059 & 0.025 & 0.028 \\
\hline
\end{tabular}

Note: All regressions are based on 105 observations. Tier 1 relative excess capital is defined as the Tier 1 excess capital of the target bank divided by the Tier 1 excess capital of the acquirer bank. The corresponding definition applies to total relative excess capital. For each independent variable the top row reports the estimated coefficient and the bottom row reports the t statistic against the null hypothesis of zero. ***, **, and * indicate significance at the $10 \%$, $5 \%$, and $1 \%$ level respectively. 